\title{
FORMATION OF MANAGEMENT MECHANISMS OF WAREHOUSE LOGISTICS IN UKRAINIAN AIC
}

\author{
Potapova Nadiya ${ }^{1}$, Kachurovskyy Serhii ${ }^{2}$, Ushkalenko Irina ${ }^{3}$, Volontyr Lyidmyla ${ }^{4}$ \\ ${ }^{1}$ Assoc. prof. Vinnytsia National Agrarian University 21008, Vinnytsia, Soniachna str. 3 Telephone: \\ +380675828132 e-mail: potapova.nadin@gmail.com \\ ${ }^{2} \mathrm{Ph}$. D. senior lecturer of department of modeling and information technologies in economics \\ 21008, Vinnytsia, Soniachna str. 3, Vinnytsia National Agrarian University 21008, \\ Vinnytsia,Soniachna str.3 Telephone: +30671751185E-mail: kach1987@ukr.net \\ ${ }^{3}$ Assoc. prof. Vinnytsia National Agrarian University 21008, Vinnytsia,Soniachnastr. 3 Telephone: \\ +380679118083 e-mail: irinavnau@gmail.com \\ ${ }^{4}$ Assoc. prof. Vinnytsia National Agrarian University 21008, Vinnytsia, Soniachna str. 3 Telephone: \\ +38096 45712 98e-mail: potapova.nadin@gmail.com
}

Received 1608 2019, Accepted 20092019

The article deals with the main mechanisms of management of storage logistics of AIC at the national level. The system of AIC warehouse management logistics contains five main mechanisms. An effective mechanism of warehouse logistics management is introduced. It requires a comprehensive conceptual and methodical approach to its evaluation. In the developed method, based on the system characteristics of the warehouse operation, account was taken: the policy of their use, the coordination and administration of flows, the impact of warehousing risks on economic activity. The developed mechanisms of warehouse logistics management, together with mathematical calculations, create a synergistic effect from their implementation. Further research in this area will make it possible to improve the processes of managing logistics flows at enterprises.

Keywords: forecasting, logistics, management, mechanisms, model, risks, strategy.

JEL codes: D04; M10.

\section{Introduction}

The movement of material flows through logistic chains is impossible without concentration the necessary amount of material resources in the established places, for preservation of which the warehouses of agricultural enterprises are intended. Warehouse assists in preserving the quality of products, materials, raw materials; increasing the rhythm and organization of both production and sales; improving the use of the territory; reducing downtime of vehicles and transportation costs; release of labor force; effective organization of sales activities, etc.

Copyright (C) 2019 The Authors. Published by Vytautas Magnus University. This is an open-access article distributed under the terms of the Creative Commons Attribution-NonCommercial 4.0 (CC BY-NC 4.0) license, which permits unrestricted use, distribution, and reproduction in any medium, provided the original author and source are credited. The material cannot be used for commercial purposes. 
The modern composition is a complex technical structure, which consists of interconnected elements, has a certain structure and performs functions for the transformation of material flows, storage, processing and distribution of products to the consumers. At the same time, the warehouse is only an element of a higher-level system - the logistics chain, which forms the functional, technical and technological requirements for the warehouse system, sets goals and criteria for its optimal functioning and establishes conditions for cargo processing (Kachurovskyi, 2013; Potapova, Pavlenko, 2014).

Warehouses are the beginning and the end of all functional areas of logistics systems, commodity producers of wholesale trade of agro-industrial complex. The warehouse is an important element of the infrastructure of commodity markets and logistical systems that are actively developing in Ukraine. Including transportation costs, storage costs, inventory management and warehousing are the bulk of total logistics costs. For agribusiness enterprises, warehouse logistics allows coordinate and equalize demand and supply due to the formation of warehouse insurance and seasonal stocks of products; create conditions for the implementation of effective marketing strategies for the sale of goods; to satisfy consumer demand at the expense of more rapid response to the needs of residents, etc.

The purpose of the article is to synthesize theoretical and methodical principles and develop practical recommendations for improving the mechanisms of management of storage logistics of AIC. To achieve this goal, the tasks were set: to investigate the substantive essence of storage logistics of agribusiness enterprises and determine its place in effective management of economic activity; to identify peculiarities of activity AIC enterprises taking into account logistic approaches in management; to substantiate the conceptual principles of construction and implementation of the system of mechanisms for management of logistics of AIC storage; to improve scientific and methodical approaches to assessing the risks of warehouse logistics taking into account branch features of the AIC.

Methodology used in the article was general scientific and special methods and techniques of scientific research. The following methods were used: scientific abstraction (for the formation of theoretical generalizations, conclusions), historical (used during the study of the origin, formation and development of management mechanisms), monographic (for analysis of risks at the warehouses of the agroindustrial complex), statistical (when the average values are calculated), correlation-regression analysis. In the processing of research materials, modern technologies and applications were used.

The information base of the study consists of legislative and regulatory documents, materials of the State Statistics Committee of Ukraine, official reports of international organizations, official publications on warehouse logistics and logistics supply chain issues agricultural products, materials of scientific conferences, etc.

Many theoretical scholars paid great attention to the theoretical aspects, the current state and trends in the development of logistics, in particular warehouse logistics, among them (Velychko, Ramanauskas, 2016; Krykavskyy, Chornopyska, 2009; Oklander, 2000; Postan 2006). The methodology for an integrated approach to 
warehouse management, from the design of the warehouse network to optimize logistics processes in the warehouse, to determine the mechanism for managing the logistics system as the work of individual elements for obtaining a specific result using management tools was presented by (Chukhray, 2018; Trydid, Tankov, Kolodizieva, 2004).

Foreign scientists were interested in separate directions of warehouse logistics improvement (Bauersox, Kloss, 2001; Hadzhinsky, 2012; Dybskaya, 2005; Sergeyev, Eliashevych, 2014) and others. The scientific approaches for storage logistics, in particular, management mechanisms, formulated in their works, play an important role in the modern logistics theory and provide an opportunity to form an idea of importance of solving current problems of storage logistics at agricultural enterprises. Defining the mechanisms for managing the storage of agricultural holdings by logistics requires further study and research to improve and efficiently manage the logistics processes in the warehouse. All this led to the choice of the topic of research, the formulation of the goal and objectives of the article.

\section{Research results and discussion}

Based on 2017year statistics, and the forecast indicators of grain and legume crops, Ukraine confidently occupies the healing sites in the three largest grain exporters. $36 \%$ of all exports of grain and crops exports to the EU countries. Second place are the countries of North Africa and the Middle East. The third place in the production is shared by Japan, China, South Korea, Indonesia, and Taiwan (Potapova, Kachurovskyy, 2016; The World bank 2018).

The harvest of wheat, corn and barley form $80 \%$ of the gross output of all export potential. Due to the growing volumes of export of grain crops, forms and organization of processes of storage of products and mechanisms of management of logistics processes in warehouses of enterprises take on actuality. That is why the problem of confident management of logistic processes are very important for the positive level of functioning in supply chains (Ramanauskas, Stašys, 2015; Hutorov, 2013).

In order to forecast the production of grain crops and sunflower, we approximate the statistical data for the last 17 years (from 2000 to 2017) with one-factor econometric models (growth curves): parabolic, hyperbolic, exponential, logarithmic.

Specification of variables. Independent variable $\mathrm{x}$ - number of time period, and dependent $\mathrm{Y}$ - production of grain crops (sunflower).

$$
\mathrm{Y}=\mathrm{f}(\mathrm{x})
$$

The adequacy of the model can be determined on the basis of the determination coefficient and Fisher's F-criterion. 


\section{Formation of Management Mechanisms of Warehouse Logistics in Ukrainian AIC Potapova Nadiya, Kachurovskyy Serhii, Ushkalenko Irina, Volontyr Lyidmyla}

Table 1. Approximation of grain crops by growth curves

\begin{tabular}{|c|l|c|c|c|c|}
\hline No. & \multicolumn{1}{|c|}{$\begin{array}{c}\text { Kind of } \\
\text { model }\end{array}$} & Econometric model & $\begin{array}{c}\text { Correlation } \\
\text { relation }\end{array}$ & $\begin{array}{c}\text { Determination } \\
\text { coefficient }\end{array}$ & F-ratio \\
\hline 1. & Parabolic & $\hat{\mathrm{Y}}=28447+1027,3 \cdot x+63,97 \cdot x^{2}$ & 0,85 & $73 \%$ & 20,3 \\
\hline 2. & Hyperbolic & $\hat{\mathrm{Y}}=52554,87-35138,7 / x$ & 0,33 & $58 \%$ & 7,9 \\
\hline 3. & Exponential & $\hat{\mathrm{Y}}=26589 \cdot \mathrm{e}^{0,0517 \mathrm{x}}$ & 0,81 & $65 \%$ & 29,7 \\
\hline 4. & Logarithmic & $\hat{\mathrm{Y}}=13338 \cdot \ln (x)+18763$ & 0,75 & $57 \%$ & 21,4 \\
\hline
\end{tabular}

The critical value of the F-ratio, determined by the statistical distribution tables of Fisher, is 4.49. According to Table 1, the following conclusions can be drawn: the relationship between the indicators is strong (in addition to the hyperbolic model). For a hyperbolic model, the relationship between indicators is weak by the Chaddock scale. By the value of the coefficient of determination, the conclusion about the adequacy of the model is impossible, and for the F-ratio, all constructed models are adequate (the estimated value is greater than the critical one). To construct a point and interval forecast, choose a power model.

Table 2. Forecast of crops production

\begin{tabular}{|c|c|c|c|c|c|c|c|}
\hline Years & Period & $\begin{array}{c}\text { Model } \\
\text { lny }\end{array}$ & $\begin{array}{c}\text { Lower } \\
\text { interval }\end{array}$ & $\begin{array}{c}\text { Upper } \\
\text { interval }\end{array}$ & $\begin{array}{c}\text { Volume of production } \\
\text { thousand ton* }\end{array}$ & $\begin{array}{c}\text { Lower } \\
\text { interval }\end{array}$ & $\begin{array}{c}\text { Upper } \\
\text { interval }\end{array}$ \\
\hline 2000 & 1 & 10,2 & 10,0 & 10,5 & 27999,7 & 22080,4 & 35505,7 \\
\hline 2001 & 2 & 10,3 & 10,0 & 10,5 & 29485,0 & 22789,4 & 38147,8 \\
\hline 2002 & 3 & 10,3 & 10,1 & 10,6 & 31049,2 & 23521,2 & 40986,6 \\
\hline 2003 & 4 & 10,4 & 10,1 & 10,7 & 32696,4 & 24276,4 & 44036,6 \\
\hline 2004 & 5 & 10,4 & 10,1 & 10,8 & 34430,9 & 25055,9 & 47313,6 \\
\hline 2005 & 6 & 10,5 & 10,2 & 10,8 & 36257,4 & 25860,5 & 50834,4 \\
\hline 2006 & 7 & 10,6 & 10,2 & 10,9 & 38180,9 & 26690,8 & 54617,2 \\
\hline 2007 & 8 & 10,6 & 10,2 & 11,0 & 40206,4 & 27547,9 & 58681,6 \\
\hline 2008 & 9 & 10,7 & 10,3 & 11,1 & 42339,3 & 28432,4 & 63048,4 \\
\hline 2009 & 10 & 10,7 & 10,3 & 11,1 & 44585,4 & 29345,4 & 67740,1 \\
\hline 2010 & 11 & 10,8 & 10,3 & 11,2 & 46950,6 & 30287,6 & 72781,0 \\
\hline 2011 & 12 & 10,8 & 10,4 & 11,3 & 49441,4 & 31260,2 & 78196,9 \\
\hline 2012 & 13 & 10,9 & 10,4 & 11,3 & 52064,2 & 32263,9 & 84015,9 \\
\hline 2013 & 14 & 10,9 & 10,4 & 11,4 & 54826,2 & 33299,9 & 90268,0 \\
\hline 2014 & 15 & 11,0 & 10,4 & 11,5 & 57734,7 & 34369,1 & 96985,3 \\
\hline 2015 & 16 & 11,0 & 10,5 & 11,6 & 60797,5 & 35472,7 & 104202,4 \\
\hline 2016 & 17 & 11,1 & 10,5 & 11,6 & 64022,8 & 36611,7 & 111956,6 \\
\hline 2017 & 18 & 11,1 & 10,5 & 11,7 & 67419,2 & 37787,3 & 120287,8 \\
\hline 2018 & 19 & 11,2 & 10,6 & 11,8 & 70995,8 & 39000,6 & 129239,0 \\
\hline 2019 & 20 & 11,2 & 10,6 & 11,8 & 74762,1 & 40252,9 & 138856,3 \\
\hline 2020 & 21 & 11,3 & 10,6 & 11,9 & 78728,2 & 41545,4 & 149189,3 \\
\hline 2021 & 22 & 11,3 & 10,7 & 12,0 & 82904,7 & 42879,4 & 160291,2 \\
\hline 2022 & 23 & 11,4 & 10,7 & 12,1 & 87302,8 & 44256,3 & 172219,2 \\
\hline Summ: & & 248,6 & 238,1 & 259,1 & 1205181,0 & 734887,5 & 2009400,9 \\
\hline Averege & & 13,8 & 13,2 & 14,4 & 66954,5 & 40827,1 & 111633,4 \\
\hline Averege by & & 11,3 & 10,6 & 11,9 & 78938,7 & 41586,9 & 149959,0 \\
forecast & & & & & & & \\
\hline
\end{tabular}

* The theoretical volume of production of grain crops and legumes, thousand tons 
Consequently, on average for the next five years, the production of grain and legume crops will be about 78,938.7 thousand tons or in the range from 41586.9 to 149959.0 thousand tons.

The use of the least squares method (MLS) involves the calculation taking into account internal periodic fluctuations and intervals of the forecast. The calculation of intervals allows to determine the area in which the predicted value of the parameter will be with a certain probability (probability P). The risk of error is determined by the level of significance $\alpha$, which corresponds to this interval: $\alpha=1-\mathrm{P}$ (Potapova, 2017; Ushkalenko, Vovk, 2013).

Table 3. Approximation of sunflower production by growth curves

\begin{tabular}{|c|l|c|c|c|c|}
\hline No. & Kind of model & Econometric model & $\begin{array}{c}\text { Correlation } \\
\text { relation }\end{array}$ & $\begin{array}{c}\text { Determination } \\
\text { coefficient }\end{array}$ & F-ratio \\
\hline 1. & Parabolic & $\hat{\mathrm{Y}}=2572+155,3 \cdot x+24,33 \cdot x^{2}$ & 0,97 & $95 \%$ & 141,5 \\
\hline 2. & Hyperbolic & $\hat{\mathrm{Y}}=8661,402-8717,99 / x$ & 0,33 & $58 \%$ & 8,0 \\
\hline 3. & Exponential & $\hat{\mathrm{Y}}=2448 \cdot \mathrm{e}^{0,0965 \mathrm{x}}$ & 0,96 & $92 \%$ & 188,8 \\
\hline 4. & Logarithmic & $\hat{\mathrm{Y}}=3629,9 \cdot \ln (x)+370,93$ & 0,83 & $69 \%$ & 35,7 \\
\hline
\end{tabular}

According to Table 3 easy to notice that the connection between the indicators in addition to the hyperbolic model is very strong, the determination coefficient of the parabolic and exponential model is more than 90\%, so these models can be chosen for constructing forecasts. We will give an advantage to the exponential model, since for it the value of the F-ratio is greater.

The values obtained on the basis of the least squares method are averaged values that are calculated on the basis of the received empirical connection for each fixed value of the logistic process parameter for each period.

Forecast of cereals production on the foot of five years is 18758,9 thousand tons. Interval forecast - from 11648,2 ths. tons to 30223,8 thousand tons

In the conditions of price fluctuations and uncontrollability of the environment for agribusiness enterprises, there is a danger of losing the possibility of adequate strategic management and the reliability of information saturation of decision-making processes (Kachurovskyi, 2016). In this regard, there is a need for the development of specific methods and mechanisms capable of forming a stable response to perturbation of the external environment. 
Formation of Management Mechanisms of Warehouse Logistics in Ukrainian AIC Potapova Nadiya, Kachurovskyy Serhii, Ushkalenko Irina, Volontyr Lyidmyla

Table 4. Forecast of sunflower production

\begin{tabular}{|c|c|c|c|c|c|c|c|}
\hline Years & Period & $\begin{array}{c}\text { Model } \\
\text { lny }\end{array}$ & $\begin{array}{c}\text { Lower } \\
\text { interval }\end{array}$ & $\begin{array}{c}\text { Upper } \\
\text { interval }\end{array}$ & $\begin{array}{c}\text { Theoretical production of } \\
\text { sunflower, ths. Tons }\end{array}$ & $\begin{array}{c}\text { Lower } \\
\text { interval }\end{array}$ & $\begin{array}{c}\text { Upper } \\
\text { interval }\end{array}$ \\
\hline 2000 & 1 & 7,9 & 7,7 & 8,1 & 2697,0 & 2261,6 & 3216,2 \\
\hline 2001 & 2 & 8,0 & 7,8 & 8,2 & 2970,2 & 2453,9 & 3595,2 \\
\hline 2002 & 3 & 8,1 & 7,9 & 8,3 & 3271,2 & 2662,6 & 4018,9 \\
\hline 2003 & 4 & 8,2 & 8,0 & 8,4 & 3602,6 & 2889,0 & 4492,5 \\
\hline 2004 & 5 & 8,3 & 8,1 & 8,5 & 3967,7 & 3134,7 & 5021,9 \\
\hline 2005 & 6 & 8,4 & 8,1 & 8,6 & 4369,7 & 3401,3 & 5613,7 \\
\hline 2006 & 7 & 8,5 & 8,2 & 8,7 & 4812,4 & 3690,6 & 6275,3 \\
\hline 2007 & 8 & 8,6 & 8,3 & 8,9 & 5300,0 & 4004,5 & 7014,8 \\
\hline 2008 & 9 & 8,7 & 8,4 & 9,0 & 5837,1 & 4345,0 & 7841,4 \\
\hline 2009 & 10 & 8,8 & 8,5 & 9,1 & 6428,5 & 4714,6 & 8765,5 \\
\hline 2010 & 11 & 8,9 & 8,5 & 9,2 & 7079,8 & 5115,5 & 9798,5 \\
\hline 2011 & 12 & 9,0 & 8,6 & 9,3 & 7797,2 & 5550,6 & 10953,2 \\
\hline 2012 & 13 & 9,1 & 8,7 & 9,4 & 8587,2 & 6022,6 & 12243,9 \\
\hline 2013 & 14 & 9,2 & 8,8 & 9,5 & 9457,3 & 6534,8 & 13686,8 \\
\hline 2014 & 15 & 9,3 & 8,9 & 9,6 & 10415,6 & 7090,6 & 15299,7 \\
\hline 2015 & 16 & 9,3 & 8,9 & 9,7 & 11470,9 & 7693,6 & 17102,7 \\
\hline 2016 & 17 & 9,4 & 9,0 & 9,9 & 12633,2 & 8347,9 & 19118,2 \\
\hline 2017 & 18 & 9,5 & 9,1 & 10,0 & 13913,2 & 9057,8 & 21371,2 \\
\hline 2018 & 19 & 9,6 & 9,2 & 10,1 & 15322,9 & 9828,2 & 23889,7 \\
\hline 2019 & 20 & 9,7 & 9,3 & 10,2 & 16875,5 & 10664,0 & 26704,9 \\
\hline 2020 & 21 & 9,8 & 9,4 & 10,3 & 18585,4 & 11570,9 & 29852,0 \\
\hline 2021 & 22 & 9,9 & 9,4 & 10,4 & 20468,5 & 12555,0 & 33369,9 \\
\hline 2022 & 23 & 10,0 & 9,5 & 10,5 & 22542,4 & 13622,7 & 37302,4 \\
\hline Summ: & 206,1 & 198,3 & 213,9 & 218405,4 & 147212,1 & 326548,3 \\
\hline Averege: & 11,5 & 11,0 & 11,9 & 12133,6 & 8178,5 & 18141,6 \\
\hline Averege by & 9,8 & 9,4 & 10,3 & 18758,9 & 11648,2 & 30223,8 \\
forecast & & & & & & & \\
\hline
\end{tabular}

There are three main types of adaptation mechanisms (Shumylova, 2006):

1. Mechanisms with passive adaptation that determine the functioning of the enterprise in a stable and more definite environment by alternatively selecting operating models from those already existing in this segment of the environment.

2. Mechanisms with active adaptation aimed at the active use of the elements of the environment to search for models of activity in the new conditions and transition to them.

3. Mechanisms aimed the formation of the external environment, used to create the most favorable conditions for the operation of the enterprise by changing the elements of the environment.

The main function of adaptive mechanisms is to choose the methods of interaction between the enterprise and the external environment. In order to 
implement selected strategies, the enterprise forms a system of mechanisms corresponding to its structure and management functions.

Warehouse logistics combines the main operational processes of enterprises, which, in different conditions of operation of the enterprise, the established system of management mechanisms should ensure the integrity and continuity of the supply chain in the process of bringing it to the consumer.

Table 5. System of mechanisms of management of warehouse logistics of AIC enterprises

\begin{tabular}{|c|c|c|c|c|c|}
\hline $\begin{array}{l}\text { The structure } \\
\text { of the } \\
\text { mechanisms }\end{array}$ & $\begin{array}{l}\text { Organizational } \\
\text { mechanism of } \\
\text { warehouse } \\
\text { management }\end{array}$ & $\begin{array}{c}\text { The mechanism } \\
\text { of financial } \\
\text { flows } \\
\text { management }\end{array}$ & $\begin{array}{l}\text { The mechanism of } \\
\text { information flow } \\
\text { management }\end{array}$ & \begin{tabular}{|c|} 
The mechanism of \\
controlling the \\
processes of storage
\end{tabular} & $\begin{array}{c}\text { Risk } \\
\text { Management } \\
\text { Mechanism }\end{array}$ \\
\hline Aim & $\begin{array}{c}\text { Design of } \\
\text { warehouse } \\
\text { infrastructure, } \\
\text { pipeline network or } \\
\text { warehouse }\end{array}$ & \begin{tabular}{|l} 
Development of \\
a system of \\
financial \\
support for \\
warehouse \\
logistics \\
facilities taking \\
into account the \\
priority of their \\
construction \\
and functional \\
purpose
\end{tabular} & $\begin{array}{c}\text { Designing and } \\
\text { developing an } \\
\text { information system } \\
\text { based on the } \\
\text { principles of } \\
\text { completeness and } \\
\text { optimization of } \\
\text { information traffic } \\
\text { in the commodity } \\
\text { network } \\
\text { (warehouse) }\end{array}$ & \begin{tabular}{|} 
Development of a \\
comprehensive \\
decision support \\
system in \\
warehouse logistics \\
through the \\
generation of a \\
function of \\
influence on the \\
deviation of the \\
basic parameters of \\
functioning
\end{tabular} & \begin{tabular}{|c|} 
Development \\
of a decision- \\
making system \\
in the event of a \\
risk storage \\
event on \\
warehouse \\
logistics based \\
on minimization \\
of their negative \\
impacts
\end{tabular} \\
\hline $\mathrm{Ta}$ & \begin{tabular}{|c|} 
1. Choosing an \\
alternative way of \\
forming a \\
warehouse \\
subsystem (own \\
construction, lease, \\
operator's services) \\
2. Definition of \\
functional \\
properties of \\
warehouses \\
(ordinary, temp.) \\
3. Determination of \\
technical and \\
technological \\
parameters of the \\
composition \\
(capacity, size, \\
equipment, etc.). \\
4. Recruitment
\end{tabular} & $\begin{array}{l}\text { 1. Prioritization } \\
\text { of objects for } \\
\text { financing } \\
\text { logistics } \\
\text { warehouse } \\
\text { infrastructure } \\
\text { 2. Finding and } \\
\text { identifying } \\
\text { sources of } \\
\text { funding } \\
\text { 3. Determinatio } \\
\text { n of volumes } \\
\text { and financing } \\
\text { schemes } \\
\text { 4. Preliminary } \\
\text { estimation of } \\
\text { economic } \\
\text { results on the } \\
\text { forecast } \\
\text { amounts of } \\
\text { financing }\end{array}$ & $\begin{array}{l}\text { 1. Choosing an } \\
\text { alternative way of } \\
\text { software hardware } \\
\text { (own or external } \\
\text { development) } \\
\text { 2. Determination of } \\
\text { areas of } \\
\text { informatization in } \\
\text { the warehouse (full } \\
\text { or partial } \\
\text { informatization) } \\
\text { 3. Determining the } \\
\text { model of service of } \\
\text { the system (own } \\
\text { staff or outsourcing) } \\
\text { 4. Definition of } \\
\text { information security } \\
\text { elements } \\
\text { 5. Identify } \\
\text { opportunities for } \\
\text { expansion }\end{array}$ & \begin{tabular}{|} 
1. Definition of \\
control points and \\
indicators in the \\
warehouse logistics \\
system \\
2. Development of \\
controlling model \\
taking into account \\
the regulatory \\
monitoring regime \\
at control points \\
3. Determination of \\
deviations of \\
parameters and \\
degree of their \\
threat to warehouse \\
activity \\
4. Formation of the \\
function of \\
influence
\end{tabular} & $\begin{array}{l}\text { 1. Defined in the } \\
\text { supply chain of } \\
\text { the main } \\
\text { locations of } \\
\text { warehouse } \\
\text { logistics risks } \\
\text { 2. Carry out } \\
\text { qualitative and } \\
\text { quantitative } \\
\text { analysis to } \\
\text { determine the } \\
\text { level of risk } \\
\text { 3. Selection of } \\
\text { methods and } \\
\text { neutralization of } \\
\text { possible risks }\end{array}$ \\
\hline
\end{tabular}

The system of mechanisms for the implementation of strategic warehouse logistics management is based on the adaptation of stream management to the environment conditions, the main elements of which are given in Table 6 . The system 
of warehouse logistics management systems of the AIC includes five main mechanisms: the organizational mechanism of warehouse management, the mechanism of financial flows management, the mechanism of information flows management, the mechanism of controlling the processes of storage and the mechanism of risk management (Potapova, 2017). The proposed mechanisms should be included in the system of strategic management as elements of the overall management system.

\section{Table 6. System of mechanisms of management of warehouse logistics of AIC}

enterprises

\begin{tabular}{|c|c|c|c|c|c|}
\hline $\begin{array}{c}\text { The } \\
\text { structure of } \\
\text { the } \\
\text { mechanisms }\end{array}$ & $\begin{array}{l}\text { Organizational } \\
\text { mechanism of } \\
\text { warehouse } \\
\text { management }\end{array}$ & $\begin{array}{c}\text { The mechanism } \\
\text { of financial } \\
\text { flows } \\
\text { management }\end{array}$ & $\begin{array}{c}\text { The mechanism of } \\
\text { information flow } \\
\text { management }\end{array}$ & \begin{tabular}{|c|} 
The mechanism of \\
controlling the \\
processes of storage
\end{tabular} & $\begin{array}{c}\text { Risk } \\
\text { Management } \\
\text { Mechanism }\end{array}$ \\
\hline $\begin{array}{l}\text { Means of } \\
\text { realization: } \\
\text { State level }\end{array}$ & $\begin{array}{l}\text { 1. Creation and } \\
\text { restructuring of state } \\
\text { bodies on the issues } \\
\text { of operation of } \\
\text { logistics } \\
\text { 2. Development of } \\
\text { strategic plans for } \\
\text { the development of } \\
\text { warehouse } \\
\text { infrastructure within } \\
\text { the framework of an } \\
\text { integrated logistics } \\
\text { strategy of the state }\end{array}$ & $\begin{array}{c}\text { Development } \\
\text { and } \\
\text { implementation } \\
\text { of targeted state } \\
\text { financing } \\
\text { programs for } \\
\text { logistic } \\
\text { (warehouse) } \\
\text { infrastructure, } \\
\text { investment } \\
\text { projects in the } \\
\text { construction of } \\
\text { warehouses, } \\
\text { support of } \\
\text { preferential } \\
\text { crediting regime }\end{array}$ & \begin{tabular}{|c|} 
Ensuring the \\
functioning of a \\
single information \\
space (including \\
Internet \\
technologies) in \\
supply chains of \\
agricultural \\
products
\end{tabular} & $\begin{array}{c}\text { Monitoring of tasks } \\
\text { execution, } \\
\text { development and } \\
\text { presentation of } \\
\text { regulatory reports } \\
\text { within the terms of } \\
\text { execution of the } \\
\text { corresponding } \\
\text { programs. }\end{array}$ & $\begin{array}{c}\text { Development and } \\
\text { implementation } \\
\text { of the main } \\
\text { provisions of risk } \\
\text { management in } \\
\text { the strategic } \\
\text { management of } \\
\text { logistics } \\
\text { warehousing }\end{array}$ \\
\hline $\begin{array}{l}\text { Regional } \\
\text { level }\end{array}$ & $\begin{array}{l}\text { 1. Creation of } \\
\text { coordination and } \\
\text { advisory bodies } \\
\text { 2. Development and } \\
\text { implementation of } \\
\text { regional programs } \\
\text { for the design and } \\
\text { construction of } \\
\text { warehouse } \\
\text { infrastructure }\end{array}$ & $\begin{array}{c}\text { Development } \\
\text { and financing of } \\
\text { regional } \\
\text { investment } \\
\text { projects in } \\
\text { warehouse } \\
\text { logistics }\end{array}$ & $\begin{array}{c}\text { Creation of } \\
\text { automated control } \\
\text { and information } \\
\text { management centers }\end{array}$ & \begin{tabular}{|} 
Monitoring of key \\
performance \\
indicators, \\
analyzing and \\
summarizing the \\
results of program \\
implementation, \\
developing \\
promising solutions
\end{tabular} & \begin{tabular}{|} 
Forecasting of \\
possible \\
warehousing \\
logistics risks, \\
diversification of \\
goods and \\
transport flows, \\
insurance
\end{tabular} \\
\hline $\begin{array}{c}\text { Enterprise } \\
\text { level }\end{array}$ & $\begin{array}{l}\text { 1. Integration forms } \\
\text { of management } \\
\text { (consumer } \\
\text { cooperatives, } \\
\text { clusters, etc.). } \\
\text { 2. Development of } \\
\text { system logistics } \\
\text { strategies of the } \\
\text { enterprise }\end{array}$ & $\begin{array}{l}\text { The amount of } \\
\text { financing of } \\
\text { enterprises, the } \\
\text { system of } \\
\text { distribution of } \\
\text { profits, the } \\
\text { system of } \\
\text { motivations }\end{array}$ & \begin{tabular}{|c|} 
Introduction of \\
information and \\
analytical system of \\
warehouse \\
administration \\
within the \\
framework of the \\
general information \\
conception of \\
enterprise logistics \\
management
\end{tabular} & $\begin{array}{c}\text { Introduction of a } \\
\text { single system of } \\
\text { controlling in the } \\
\text { enterprise, taking } \\
\text { into account all the } \\
\text { main functions }\end{array}$ & \begin{tabular}{|c|} 
Comprehensive \\
inventory \\
management \\
program, \\
property \\
protection, \\
insurance, \\
hedging of \\
market \\
operations
\end{tabular} \\
\hline
\end{tabular}


The system of warehouse logistics management mechanisms includes a set of interrelated mechanisms, the functioning of which is aimed at the implementation of a single goal to optimize the flow of resources in warehouses in supply chains of agricultural products (Dzhonson, Donald, Vordlou, Merfyml 2002; Shramenko, Kokhanovska, 2010). The main task of constructing efficient warehouse logistics management mechanisms is to develop a set of scientific methods and tools that influence logistics processes in order to optimize and improve the existing logistic infrastructure of warehouses in the long run and in real time period (Dybskaia, 2005; Potapova, Kachurovskyi, 2014).

When storing in agriculture take into account that most products must withstand specific storage conditions. This is due to the use of specialized warehouses (elevators, refrigerators, fruit storage, etc.) for storing stocks at all stages of the material flow, from the source of its occurrence to the final consumer (Postan, 2006; Savyn, 2001). The logistics of warehousing in the AIC covers all areas and appears as an integrated part of the output from raw materials (production at agricultural enterprises to the deep stages of its processing (food processing and other processing industry) rental rates, most companies tend to decide on the construction of their own warehouses (Volynchuk, 2012). However, the construction of its own stock is always associated with significant capital expenditures, which in rendering storage facilities provide an opportunity for rapid response to market changes in accordance to the requirements for storage of products, but the significant dependence of payment from the requirements of the lesser carries a weighty one share of the risk of the warehouse infrastructure project. One of the alternative solutions can be considered the introduction of outsourcing, that is, the transfer of the warehousing function to the logistics operator. Outsourcing can be implemented in three directions: IT outsourcing (creation of information resources and servicing by outside specialized companies); production outsourcing (transfer of part of operations to third-party manufacturers); outsourcing of business processes (transfer of individual business processes to third-party executors) (Chukhray, 2007).

\section{Conclusions}

Effective logistics is a guarantee of ensuring the continuity of agro-logistic supply chains. Infrastructure component of logistics is determined by objects that are, to some extent, involved in the formation of the capacity of resource flows. Agrologistic has a number of features, among them there are seasonality of the technological process of cultivation and special conditions of storage of products. This determines the need to focus on logistics warehousing in the agricultural sector.

Creating mechanisms of management logistics warehousing farms, based on the principles of consistency, adaptability must provide storage networks to change the conditions of competition and commodity markets. Due to this regard, we are talking about a system of warehouse logistics mechanisms that include components: organizational, financial, information, controlling and risk prevention. Each 


\section{Formation of Management Mechanisms of Warehouse Logistics in Ukrainian AIC Potapova Nadiya, Kachurovskyy Serhii, Ushkalenko Irina, Volontyr Lyidmyla}

component is defined by its goals, tasks and multi-level means of implementation (from micro-logistic to macro-level).

The researches have established and substantiated the conceptual principles of construction and implementation of the system of mechanisms for management of warehousing logistics of AIC on the basis of a balanced proportion of complementary adaptation mechanisms that are able to reduce the risks of emergence under the influence of the external environment. The system of warehouse management logistics management systems of AIC contains five main mechanisms: the organizational mechanism of warehouse management, the mechanism of financial flows management, the mechanism of information flows management, the mechanism of controlling the processes of storage and the mechanism of risk management.

The obtained results of the study provided an opportunity to clarify the functional characteristics of storage logistics of agribusiness enterprises, which objectively confirms the importance of using warehouses as a central link in the coordination of supply flows and distribution of material flows. In the conditions of the expanded flow of information, with the accompaniment of the material flow, there is a need for the introduction of logistics processes, which are enable to establish a monitoring mode for the occurrence of risks at control points and to regulate the received deviations.

\section{References}

Bauersoks, D., Kloss, D. (2001). Lohystyka: intehryrovannaia tsep postavok. M.: ZAO "Olymp-Byznes", 640 p.

Chukhray, N. (2007). Autsorsynh v lohistytsi: yevropeiskyi ta ukrainskyi dosvid. http://www.ukrlogist.com/article/operacionnyj-menedzhment/249.

Chukhray, N. I. (2018). Cold supply chains of thermally labile products and their competitiveness // Lvivska politekhnika. No. 19: 85-102.

Dybskaia, V. (2005). Lohystyka skladyrovanyia dlia praktykov. M.: Alfa-Press, 208 p.

Dzheims S. Dzhonson, Donald F. Vud, Dэnyэl L. Vordlou, Pol R. Merfyml (2002). // Sovremennaia lohystyka: Per. s anhl, 7-e yzd. M.: Vyliams, p. 615.

Hadzhynskyi, A. (2012). Proektyrovanye tovaroprovodiashchykh system na osnove lohystyky. M. // Izdatelskaia torhovaia korporatsyia, $324 \mathrm{p}$.

Hutorov, O. (2013). Formuvannia efektyvnoho mekhanizmu funktsionuvannia lohistychnykh system silskohospodarskykh pidpryiemstv // Ekonomika APK, No. 8, 33-38.

Kachurovskyi, S. (2013). Stratehichni zavdannia v lohistyky skladuvannia v APK. // Universytetski naukovi zapysky, 2, 223-227.

Kachurovskyi, S. (2016). Ekonomiko-matematychna model otsinky ryzykiv skladskoi lohistyky silskohospodarskykh pidpryiemstv // Ekonomika. Finansy. Menedzhment: aktualni pytannia nauky i praktyky, 16, 46-54.

Krykavskyi, Ye., Chornopyska, N. (2009). Lohistychni systemy. L.: Natsionalnyi universytet "Lvivska politekhnika", p. 684.

Oklander, M. (2000). Kontury ekonomycheskoi lohystyky. K.: Nauchnaia mysl, p. 175.

Postan, M. (2006). Ekonomyko-matematycheskye modely smeshannykh perevozok. O. // Astroprynt, $369 \mathrm{p}$. 
Potapova, N. (2017). Perspektyvy rozvytku ahrolohistyky na rynkakh silskohospodarskykh kultur // Ekonomika, finansy, menedmzhent: akutalni pytannia nauky i praktyky, 1, 28-36.

Potapova, N., Kachurovskyi, S. (2014). Upravlinnia lohistychnymy systemamy APK. Transformatsiia ekonomichnoho rozvytku systemy APK rehionu $\mathrm{v}$ rynkovykh umovakh hospodariuvannia: kolektyvna monohrafiia, 346-353.

Potapova, N., Kachurovskyy, S. (2016). Ryzyky lohistychnykh system APK. XI International scientific-practical conference // Marketing and logistics in the system of management, 226-227.

Ramanauskas, J. Stašys, R. (2015). Logistics in the System of Management of Enterprises in Agrarian Sector of Economy // Management Theory and Studies for Rural Business and Infrastructure Development. Vol. 37. No. 4: 598-602. DOI: 10.15544/mts.2015.51 [28 10 2018].

Savyn, V. (2001). Sklady: Spravochnoe posobye. M.: Delo i servys, p. 544

Serheev, V., Eliashevych, Y. (2014). Lohystyka snabzhenyia. M.: Yurait, p. 522

Shumylova, A. (2006). Mekhanyzmy realyzatsyy stratehyy orhanyzatsyy Available at: http://www.m-economy.ru/art.php?nArtId=965 [28 10 2018].

Trydid, O. M., Tankov, K. M., Kolodizieva, T. O. (2004). Vyrobnycha lohistyka. Kh.: INZhEK. p. 352

Ukraina: Otsinka spryiannia torhivli ta tranzytu (2018). The World bank. Available at: http://www.worldbank.org/en/news/press-release/2018/10/04/ukraine-economic-update-october$2018 \quad$ [28 10 2018].

Ushkalenko, I., Vovk, V (2013). Zastosuvannia metodu modelei zadach prohnozuvannia sotsialno-ekonomichnoho rozvytku rehionu. T.: TNTU im. Ivana Puliuia, 21-23.

Velychko, O., Velychko, L., Ramanauskas, J. (2016). Transformation and development of production-logistics enterprises in Ukrainian agrarian economy // Management Theory and Studies for Rural Business and Infrastructure Development, Vol. 38. No. 1: 70-87.

Volynchuk, Yu. (2012). Teoretychnyi pidkhid do vyznachennia sutnosti lohistychnykh tsentriv // Ekonomichnyi forum. ://www.nbuv.gov.ua/portal/Soc_Gum/Ekfor/2012_4/1.pdf. [28 10 2018].

\title{
SANDĖLIŲ LOGISTIKOS VALDYMO MECHANIZMŲ FORMAVIMAS UKRAINOS AIC
}

\author{
Potapova Nadiya $^{1}$, Kachurovskyy Serhii ${ }^{2}$, Ushkalenko Irina ${ }^{3}$, Volontyr Lyidmyla ${ }^{4}$ \\ ${ }^{1-4}$ Vinnytsia nacionalinis žemès ūkio universitetas, Ukraina
}

Pateikta 201908 16, Priimta 20190920

Straipsnyje aptariami pagrindiniai AIC saugojimo logistikos valdymo mechanizmai nacionaliniu lygmeniu. AIC sandèlių valdymo logistikos sistemą sudaro penki pagrindiniai mechanizmai. Pristatomas efektyvus sandèlių logistikos valdymo mechanizmas. Jo vertinimui reikalingas išsamus konceptualus ir metodinis požiūris. Taikant sukurtą metodą, pagrịstą sandèlio operacijų sistemos charakteristikomis, buvo atsižvelgta i sandèlių naudojimo politiką, srautų koordinavimą ir administravimą, sandèliavimo rizikos poveikį ekonominei veiklai. Sukurti sandèlių logistikos valdymo mechanizmai kartu su matematiniais skaičiavimais sukuria sinergetini jų igyvendinimo efektą. Tolesni šios srities tyrimai leis pagerinti logistikos srautų valdymo procesus logistikos įmonèse.

Raktiniai žodžiai: prognozavimas, logistika, valdymas, mechanizmai, modelis, rizika, strategija.

JEL kodai: D04; M10. 